\title{
Speaker positioning in interpreter-mediated press conferences
}

\author{
Christina Schäffner
}

Aston University

This article investigates potential effects which (the recontextualisation of) interpreted discourse can have on the positioning of participants. The discursive event which forms the basis of the analysis are international press conferences which bring politicians and journalists together. The dominant question addressed is: (How) do interpreter-mediated encounters influence the positioning of participants and thus the construction of interactional and social roles? The article illustrates that methods of (critical) discourse analysis can be used to identify positioning strategies which are employed by participants in such triadic exchanges. The data come from press conferences which involve English, German, and French as source and target languages.

Keywords: press conference, positioning, interactional role, social role, recontextualisation

\section{Introduction}

Political communication across national borders often involves translation and interpreting. Discursive practices in the domain of politics (e.g., election campaigns) result in institutional types of political discourse (e.g., coalition treaty). Some of these discursive events (e.g., bilateral meetings of heads of government, international press conferences) are mediated by an interpreter, or texts which are the outcome of meetings (e.g., agreements) are translated.

In disseminating politics to the public, mass media play an important role. Media, however, do not purely disseminate information about political events, but critically engage with them (e.g., Ekström and Patrona 2011). Some discursive events are actually constituted by the interaction of politicians and media representatives, with interviews and press conferences as typical examples. Both of these discourse types have been analysed from the point of view of (critical) discourse analysis, interactional sociolinguistics, (socio)pragmatics, and dialogue studies (e.g., Bhatia 2006; Clayman and Heritage 2002a; 2002b; Fetzer and Bull 2013; Weizman 2008). In most of these studies, monolingual interaction was analysed. In this article, I will illustrate how interpreter-mediated interaction between politicians and journalists can contribute to role positioning and thus to the construction of politics and politicians. The focus will be on press conferences, and the investigation is conducted from the perspective of translation studies, although concepts of discourse analysis are employed.

\section{Discourse analysis and interviews}

Discourse analysis as "a domain of scholarly practice" (van Dijk 2008, 2) for the examination of the structure and function of language in use adopts a variety of methods, depending on the 
aims of investigation (see, e.g., Wodak and Meyer 2001). Critical discourse analysis is "a way of doing discourse analysis from a critical perspective" (Baker et al. 2008, 273), for example, explaining under which circumstances specific linguistic choices have (not) been made by text producers and examining what kinds of power relations such choices reflect. Scholars in translation and interpreting studies have also frequently drawn on (critical) discourse analysis frameworks (e.g., Hatim and Mason 1990; Munday 2012). A more extensive analysis of methods adopted in (critical) discourse analysis, or of translation studies research using such methods, cannot be undertaken for the purpose of this article. Only a brief overview of some research on political interviews which particularly inspired this specific study (esp. Weizman 2008) will thus be provided.

Scholars who draw on discourse analysis, and also on (socio)pragmatics, for the investigation of monolingual news interviews, have highlighted, for example, turn-taking mechanisms, face work, shifts of footing as well as genre conventions and deviations from such conventions (e.g., in respect of coherence between questions and answers). Clayman and Heritage (2002a) investigated openings and closings, types of questioning (i.e., defensible questioning and adversarial questioning), answers and evasions. They showed, for example, how these types of questioning are related to neutralism, credibility, legitimacy and how they function in setting agendas and exerting pressure, respectively. Based on the analysis of political interviews in British public service broadcasting, Montgomery (2011) illustrates discursive changes in the accountability interview, reflected, above all, in departures from the canonical question-answer structure to a turn-taking structure of assertion (by the journalist) counter-assertion (by the politician). This discursive change in the structure also reflects a change from deference to adversarialism in attitude and role perception. A changing tenor of questioning is also identified by Heritage and Clayman (2013) for American journalists, illustrated with the use of the negative interrogative question form. Fetzer (2007) added a comparative perspective to the analysis of challenges in political interviews by investigating culture-specific differences, involving interviews with British and German politicians and journalists. Such studies go beyond the analysis of discourse internal structures and features, and reveal institutional power and (more or less) hidden agendas, as well as role perceptions.

Role positioning in media interviews is the main focus of Weizman (2008). Her corpus consisted of news interviews in TV studios, an institutional setting which includes a journalist as the interviewer, a politician as the interviewee, and the audience. She illustrates how this copresence of the audience influences the discursive strategies in positioning and identity construction. Weizman analyses news interviews as dialogic interaction and as instances of institutional discourse. She argues that participants "constantly position themselves explicitly and implicitly, and by so doing reciprocally position their interlocutors and their audiences" (3). In this way, a "complex system of interactional and social roles and identities is established through negotiations" (ibid). Positioning is mutual; that is, a journalist can position a politician by assigning a role or an identity to him or her, and vice versa. Either participant can of course also position himself or herself in a particular way. Weizman points out that roles are social constructs, and this applies equally to interactional and social roles. Interactional roles have to do with the speakers' roles and obligations in the interaction, whereas social roles have to do with the "social obligations involved in the speakers' roles outside the interaction itself" (26). 
Participants normally have several roles, and any role can become or can be made relevant as it suits the interaction or the interactional partner. For example, an interviewee can be a cabinet minister and at the same time a wife, a mother, and a football fan. In an interview about, let's say, a government's plan to raise taxes, the politician can position herself as a strong supporter of tight budget control and immediately switch into the role of a housewife who is conscious of the family budget when she does the weekly shopping. Participants also position themselves in terms of power. In respect of the interactional roles, power - or more precisely, an asymmetry of power - can be seen in the length of turns, in interruptions, topic initiation, agenda management, etc. (ibid.). Power asymmetry is also evident when a participant positions him- or herself as confident, apologetic, dominant, submissive, etc. (14). Weizman argues that either role can be challenged and in her analysis of political news interviews she illustrates the challenge potential of, among others, irony and framing through terms of address.

Positioning in news interviews thus "involves assignment, shaping and negotiations of reciprocal relations between all parties involved in the interaction" (16). The majority of the news interviews Weizman analyses involve only two participants: a politician and a journalist (although a few of her cases are multi-party interviews with two or three interviewees). In each case, the interaction is monolingual (mostly Hebrew). Political interviews, however, may be mediated by an interpreter. They are therefore not only dialogic, but triadic exchanges (Mason 2001). The same applies to press conferences, which are also a case of interaction between journalists and politicians. The main difference is that there are always several journalists asking questions and each of them is usually allowed only one turn (which often leads to complex questions).

Among the few cases which focus exclusively on the analysis of interpreter-mediated interviews in the context of politics are the studies by Wadensjö (2000; 2009) and Baker (1997). In their interactionistic approach to interpreter-mediated encounters, both make use of concepts from discourse analysis, such as turn-taking and face work, revealing, among others, links between the interpreted utterances and the ideological positioning of the speakers (further explained in Baker 2006 with reference to power-sensitive definitions of context). In focussing on press conferences, this article is another contribution to analysing the complexity of such triadic exchanges in the field of politics. The main question I want to address is as follows: (How) do interpreter-mediated encounters influence the positioning of participants and thus the construction of interactional and social roles? This question will be investigated with reference to interpreter-mediated press conferences conducted in English, German and/or French.

\section{Corpus and method}

The discursive event of a political press conference following a state visit shows a specific pattern: initial statements by the politicians, starting with the host, followed by questions from the journalists and answers by the politicians. Journalists subsequently report about press conferences in articles which usually include extracts of statements presented in direct or indirect speech. Interpreting at such press conferences is more frequently provided in the simultaneous mode, which, however, makes the triadic exchange less visible. Depending on circumstances and/or previous agreements, the consecutive mode is also sometimes practised. 
Complete transcripts of press conferences are often made available on the websites of both governments as monolingual texts in each case. It is now also becoming more common that video recordings of the press conference are made available on the host's website. They can also often be accessed from YouTube.

The data used for this article are the transcripts as available on the respective government websites and the video recordings, if provided. As a first step, the different language versions of the transcripts were compared in order to identify any differences, such as omissions or noticeable shifts. These transcripts, however, are already the result of recontextualisation processes which often include transformations carried out by political advisors or government officials, depending on the practices in the respective countries (Schäffner 2012a). As a second step, the video recordings were used to identify the actual words of all participants and compared to the transcripts. Since we are dealing with interpreter-mediated events, the actual voices of the participants are not always audible, which puts limits to the analysis. Watching the video, however, also allows, up to a point, to incorporate other semiotic codes (such as body language and pauses) into the analysis.

This study is part of a wider project to investigate the role of translation and interpreting in political discourse and political institutions (e.g., Schäffner 2012b). Although it is informed by discourse analysis, the focus is on the interpreter-mediated press conference as a situated practice. This means that it does not take concepts from discourse analysis, such as speech acts or turn-taking, as its starting point in order to find examples of them in the corpus. Nor is it intended to identify typical patterns solely in the interpreting strategies. The aim of the analysis is rather to investigate if and how the very fact that the press conference is mediated by interpreters impacts on the way politicians are positioned, thus also testing the applicability of Weizman's model in a multilingual and mediated context. Attention was paid above all to discursive features which signal or problematize speaker positioning.

\section{Interpreter-mediated press conference: Positioning the other's social role}

In press conferences, politicians address the journalists present in the first instance, but they also refer to themselves and to the other politician who is taking part in the discursive event. References to participants can be expressed by various forms of address, including proper name, title, and personal pronouns. Forms of address are connected with expressions of power and solidarity and are thus of importance for the construction of discursive roles and identities. How references to co-participants can pose a challenge to interpreting is illustrated in the first example, which comes from a joint press conference between the German Chancellor Angela Merkel and the British Prime Minister David Cameron. It was held on 21 May 2010 in Berlin, on the occasion of the first visit of the newly elected Prime Minister to Germany. A complete transcript of the press conference, including the questions and answers, is available in German on the website of the German government, and a transcript of the statements only is available in English on the website of the British government. A video on YouTube (indicated as 'Uploaded on 21 May 2010') includes only the statements (http://www.youtube.com/watch?v=EK6nGW1Sjvo). This video recording shows that simultaneous interpreting was provided, with Cameron wearing headphones while listening to 
Merkel's speech, whereas Merkel did not use headphones when listening to Cameron's statement. This video is a monolingual one in English. That is, viewers can hear Cameron's English voice and the voice of the simultaneous interpreter, but not Merkel's own voice in German.

Chancellor Merkel opened the press conference as follows:

(1a) Merkel ${ }^{1}$ : Meine Damen und Herren, ich freue mich, dass David Cameron, der neue britische Premierminister, uns sehr schnell hier in Berlin besucht hat. [...]

Das erste Thema, über das wir uns ausgetauscht haben, ist das Thema Koalitionen.

Darüber habe ich noch nie mit einem britischen Premierminister geredet, aber ich

habe den Eindruck, dass dieses Gespräch sehr gut war. [...]

Ganz herzlichen Dank, David, dass du heute nach Berlin gekommen bist!

(http://www.bundesregierung.de/Content/DE/Mitschrift/Pressekonferenzen/2010/05/2

010-05-21-statement-bk-cameron.html)

The transcript of the interpreter's rendering reads as follows:

(1b) Merkel: I am delighted to be able to welcome David Cameron, the new British Prime Minister and to see that he has come here so quickly [...]

[...] first we actually swapped news about coalitions and that is something that is certainly new with the British Prime Minister at least, but I have the very clear impression that this part of our conversation was very good and fruitful. [...]

Thank you, David, for coming here today.

(http://downingstreetsays.com/briefings/0110/04/22/8388)

What is noticeable in this extract is that Merkel used the informal 'du' and the first name 'David' when she addresses him directly at the end of her statement. Languages like German (and French) differentiate between the second-person non-deferential pronoun $d u$ and the deferential pronoun Sie. In English, the pronoun you can be used both deferentially and nondeferentially. As argued by Bull and Fetzer (2006, 11), "forms of address play an important role in negotiating social status in interaction." By opting for the $d u$ and the first name, Merkel positions Cameron not only in his official political role (as is done indirectly with reference to the title in the very first sentence), but also as a political friend. The use of $d u$ signals that Cameron is being welcomed into the fold of political leaders who represent conservative political parties.

Cameron's response and the interpreted version as published in the transcript are given below:

\footnotetext{
${ }^{1}$ The various websites of national governments have their own conventions for indicating the speaker in respect of their title. On the website of the German government we find the shortened forms 'BK'in' and 'PM', for Bundeskanzlerin (= Federal Chancellor) and Prime Minister, respectively. The website of the British government uses capital letters and bold, adding the name only for the visitor (e.g. CHANCELLOR MERKEL, PRIME MINISTER); similarly for the website of the French government (M. CAMERON, LE PRÉSIDENT). For the sake of simplicity and consistency, I use only the surname of the politician in bold in each example, not copying the original format and layout.
} 
(2a) Cameron: Thank you very much, Chancellor, for inviting me here today and thank you for what you have said. [...]

As you said, we started with an interesting conversation about how you best operate a coalition, something you have great expertise in. Like you, we are in partnership with Liberals and we are working out how best to make that work for our country.

(2b) Cameron: Herzlichen Dank, Frau Bundeskanzlerin, dass Sie mich eingeladen haben, und auch vielen Dank für Ihre freundlichen Worte. [...]

Natürlich haben Sie mir ein bisschen etwas darüber gesagt, wie man mit einer

Koalition am besten umgeht. Wir in Großbritannien haben damit relativ wenig

Erfahrung, aber Sie haben damit sehr große Erfahrungen und haben eine sehr gute

Partnerschaft mit der liberalen Partei hier im Lande. Wir werden versuchen, das in

Großbritannien nachzuahmen.

Cameron does not reciprocate the informal form of address, which of course would not be revealed in the use of the personal pronoun you. The interpreter too opted for the formal Sie instead of the $d u$, probably because the official title Bundeskanzlerin (as used by Cameron: 'Chancellor') would not fit with the informal $d u$. Having used the Sie in the first sentence, the interpreter continued with this decision for the remaining part of the turn. What is more interesting, however, is the second part of Cameron's comments. The interpreter's rendition back-translated into English would be as follows:

(2c) Of course, you have told me how best to operate with a coalition. We in Britain have relatively little experience with this, but you have great experience and you have a good partnership with the Liberal Party here in your country. We will try to imitate this in Great Britain.

An analysis of the German transcript alone (2b) suggests that Cameron comes across as positioning himself in an inferior role as a newcomer, as lacking in experience, and willing to learn from his more experienced German counterpart ('you have told me,' 'we will try to imitate'). In his own words, however, he does stress British independent action ("we are working out how best to make that work for our country"). His "as you said" is a cohesive device establishing coherence to a topic of Merkel's previous turn and not an acknowledgement of who said what to whom, as the interpreter's rendition suggests. The patronising perception of Merkel by a British audience is thus the result of the interpreter's rendering. Also the use of 'that' in "that is something that is certainly new with the British Prime Minister" in (1b) makes the rendition ambiguous (Merkel herself simply said that it was the first time she had talked about coalitions with a British Prime Minister). ${ }^{2}$ Cameron himself, however, does not seem to have had problems in disambiguating the reference of 'that' since in his own words he refers to

${ }^{2}$ I am grateful to one of the anonymous reviewers for pointing this out. 
the conversation they had, obviously also as a result of his knowledge of the prior discourse of the bilateral meeting.

Such interpreting errors are extremely rare in my corpus of interpreter-mediated press conferences, since the interpreters who work at such a high level of political interaction are very experienced and competent. It is difficult to judge how this error had come about, but the interpreter had surely been involved in the bilateral discussions before the press conference and it may be that such a knowledge of the wider context and discourse may have influenced his or her $^{3}$ rendition - or it may have been a matter of his/her own spatial position at the press conference (i.e., whether he/she was able to see and hear Cameron clearly).

Forms of address thus function as a framing device and contribute to positioning a participant in a discursive event. Highly conventionalised formulations are employed for opening press conferences, with politicians often using role-oriented terms of address, thus also contributing to positioning their counterpart in their social role as a politician. This use of the title is normally reciprocated in the first turn of the visiting politician. This was seen in (1a) and (2a) above and can be illustrated further from a press conference held by Angela Merkel and the Italian Prime Minister Enrico Letta (30 April 2013) on his first state visit to Berlin after taking power:

(3) Merkel: Meine Damen und Herren, ich freue mich, heute Abend den neuen Ministerpräsidenten Italiens, Herrn Enrico Letta, bei uns zu seinem Antrittsbesuch in Berlin empfangen zu können. Ich heiße ihn ganz, ganz herzlich willkommen! Ich gratuliere zu den gewonnenen Abstimmungen und freue mich, dass Ihr Weg Sie gleich nach Berlin geführt hat.

(http://www.bundeskanzlerin.de/Content/DE/Mitschrift/Pressekonferenzen/2013/04/2 013-04-30-merkelletta.html;jsessionid=0026717E9205D0B1D9F46A8B3C49882C.s3t1)

[Literally: Ladies and Gentleman, I am happy to welcome tonight the new Italian Prime Minister, Mr Enrico Letta, on his first visit to Berlin. I welcome him very, very warmly! Congratulations on the votes won, and I am happy that your path has led you so quickly to Berlin.]

In this press conference, Merkel shifts from the third person to the second person, but this time she uses the formal Sie form. Letta represents a political party whose ideological position differs from Merkel's Christian Democratic Union party. However, political differences do not seem to be the decisive criterion when it comes to positioning through forms of address; cultural conventions also seem to play as role. This can be illustrated with a press conference between David Cameron and François Hollande held on 11 July 2012 in London, where Cameron welcomes his counterpart using the first name, although both politicians represent parties of opposing political orientations. We see a similar strategy of switching between third and second person in the extract of the opening statement by Cameron below:

\footnotetext{
${ }^{3}$ Since in the video we cannot hear the voice of the interpreter who rendered Cameron's words into German, the interpreter's gender is unknown. The interpreter who rendered Merkel's words into English was female.
} 
(4a) Cameron: Good afternoon, ladies and gentlemen. I'm delighted to welcome President Hollande to Downing Street on his first presidential visit to Britain.

Bienvenue, François. It's been great to have you here today. [...] And I'm delighted that François will be coming to see some of the Games for himself. [...]. François, over to you.

(http://www.number10.gov.uk/news/pm-david-cameron-and-president-hollande-pressconference/)

In the French interpreted output, the formal vous has been used, illustrated in the transcript below and also confirmed by watching the video (see http://www.elysee.fr/videos/conferencedu-president-avec-m-david-cameron-a-londres/):

(4b) Cameron: Bonjour Mesdames et Messieurs. Je suis ravi d'accueillir le Président HOLLANDE 4 à Downing Street lors de sa lère visite présidentielle en Grande-

Bretagne, bienvenue à François, c'est très agréable d'avoir votre visite. [...] et je suis ravi de savoir que François HOLLANDE va venir assister à certaines épreuves. [...]

François, vous avez la parole.

(http://www.elysee.fr/conferences-de-presse/article/conference-de-presse-conjointede-m-le-president-de-la-republique-et-m-david-cameron-premier-ministre-duroyaume-uni-de-grande-bretagne-et-d-irlande-du-nord/)

Forms of address can pose a challenge for the interpreter, as we have seen above. If interpreters know that politicians are addressing each other in an informal way, they also opt for the $d u$ form in German. This can be illustrated with another press conference of Merkel and Cameron, held on 7 June 2012 in Berlin, where Cameron's words to Merkel are rendered into German in the informal way (Angela, $d u$ - a transcript of this press conference is not available on the website of the British government):

(5) Cameron: Herzlichen Dank, Angela, für

die warmherzige Gastfreundschaft, mit der du mich heute in Berlin willkommen geheißen hast. [...] Wie du gesagt hast, [...]

(http://www.bundesregierung.de/Content/DE/Mitschrift/Pressekonferenzen/2012/06/2012 -06-07-merkel-cameron.html?nn=391778)

The fact that at press conferences politicians tend to refer more often to each other by using the third person and the official title is due to the nature of this discursive event. As already said, politicians speak not normally to each other but above all to the journalists present. These journalists are their addressees, indicated by the 'ladies and gentlemen' at the very beginning. By extension, however, politicians also have each other and other politicians in mind as auditors. The politicians are the addressees of the journalists and they are normally addressed

\footnotetext{
${ }^{4}$ In the transcripts, capital letters are used for the proper names of the politicians participating in the press conference. Since this is a direct quote, I have not changed the format.
} 
by their title (see Examples 6 and 7 below). The politicians become each other's immediate addressee most explicitly when they change turns, as illustrated in Example 4 above. It is in these phrases which indicate turn-taking that the form of address chosen by one politician for the other is also a signal for the type of interpersonal relationship entailed. Forms of address as interactional devices at the beginning and end of a turn also function for positioning interactional roles, which will be illustrated in the next section.

\section{Interpreter-mediated press conference: Positioning the other's interactional role}

The next example comes from the joint press conference by the then French President Nicolas Sarkozy and Chancellor Angela Merkel, held on 6 February 2012 in Paris. After the initial statements, the first question from a journalist refers to the financial crisis in Cyprus. The transcript on the website of the German government reads as follows:

(6a) Frage ${ }^{5}$ : Herr Präsident, Sie haben es schon angesprochen: Die GriechenlandKrise spitzt sich wieder bedrohlich zu. Sie haben gesagt, dass sich die griechischen verantwortlichen Politiker wie auch die Opposition ihrer Verantwortung stellen müssen. Was machen Sie, wenn sie dies nicht tun? Sind Sie bereit, inzwischen einen Austritt Griechenlands aus der Eurozone in Aussicht zu nehmen? Wie stellen Sie sich die weiteren Tage vor, wenn Griechenland sich weiter Zeit auserbittet?

Sarkozy: Zunächst einmal ist Frau Merkel genau wie ich der Ansicht, dass man sich noch nie so nahe war, was eine Einigung anbelangt, was die Privatgläubiger als auch die öffentlichen Gläubiger anbelangt. Niemals waren wir einer Einigung so nahe. Aber die Bundeskanzlerin hat recht, wenn sie sagt: Wir müssen zum Abschluss kommen.

(http://www.bundeskanzlerin.de/Content/DE/Mitschrift/Pressekonferenzen/2012/02/2 012-02-06-merkel-sarkozy.html?nn=74446)

[Literally: Question: Mr President, you already mentioned it: the crisis in Greece is getting dangerously acute. You have said that the responsible Greek politicians as well as the opposition have to take responsibility. What will you do if they don't do this? Are you willing to consider a temporary Greek exit from the euro-zone? How do you imagine what will happen in the coming days if Greece requests to be given more time?

Sarkozy: First of all, Mrs Merkel exactly like me is of the opinion that we have never been so close to achieving a solution in respect of the private creditors as well as the public creditors. Never before have we been that close to an agreement. But the Chancellor is right in saying that we have to come to an agreement.]

\footnotetext{
${ }^{5}$ The transcripts record just Frage ('question') and journalists are usually not identified, neither by name nor by mentioning the newspaper they represent. At the actual press conference, they do introduce themselves, and it is by watching the video recording that it is possible for a researcher to find out who had asked the question and in which language. These self-presentations are often not interpreted.
} 
Reading this extract we may wonder why President Sarkozy would start his answer by commenting on the opinion of Chancellor Merkel and saying that she shares his own opinion. In terms of social roles, it seems that Sarkozy positions himself as an authority and Merkel is positioned as somewhat inferior to him, and with Sarkozy's expressing his appreciation of what she did ('the Chancellor is right in saying'). On the website of the French government, we get a complete transcript of the press conference in French and also access to a video (also accessible on YouTube http://www.youtube.com/watch?v=W7cWvZRtS3w). This complete French text reveals that the question-answer sequence was in fact more complex:

(6b) Question: Monsieur le Président, Madame la Chancelière, comme vous le disiez, la crise grecque menace à nouveau. Monsieur le Président de la République, vous avez dit que les responsables politiques grecs de la majorité et de l'opposition doivent assumer leurs responsabilités, qu'allez-vous faire s'ils ne le font pas? [...]

Merkel: Je crois que la question était adressée au président de la République ... Ah, c'était à nous deux? Ah bon, d'accord. Alors que le Président commence.

Sarkozy: Bon, d'abord, Madame MERKEL comme moi, nous pensons que les éléments de l'accord n'ont jamais été aussi proches. Jamais. Que ce soit pour les créanciers privés que pour les créanciers publics. Jamais nous n'avons été aussi proches d'un accord. Mais la Chancelière a raison, il faut conclure. (http://www.elysee.fr/president/les-actualites/conferences-de-presse/2012/conferencede-presse-conjointe-de-nicolas-sarkozy.12958.html)

As we can see from this transcript, the journalist initially addressed both Sarkozy and Merkel (using the second person plural: comme vous le disiez) before asking questions specifically to Sarkozy. The question initially resulted in some confusion about who the journalist's addressee was, noticeable in Merkel's Je crois que la question était adressée au président de la République ('I think the question was addressed to the President'). The video shows the two politicians looking at each other and into the audience before Merkel's intervention. We can hear some voices from the audience (indicated by the three dots after République in the transcript above) which leads to Merkel's confirming that this brief exchange had clarified the speaker roles (Ah, c'était à nous deux? Ah bon, d'accord. Alors que le Président commence 'Ah, for both of us? Well, good. Then the President begins.'). Sarkozy's initial bon can also be interpreted as a signal that he is willing to take on the speaker's role.

In this exchange then, the participants negotiated their interactional roles, asking for clarification concerning the addressee, acknowledging an intended speaker role, and accepting a speaker role. This negotiation of the interactional roles, however, goes hand in hand with a positioning of the social roles: by passing on the speaker role to Sarkozy, Merkel positions herself as the more senior politician who has the power to allocate speaking rights. This interpretation also requires a reinterpretation of Sarkozy's first sentence. As the French original text shows, he actually answered on behalf of both Merkel and himself, stressing that they share a specific point of view (using the first person plural: nous pensons) and not so much positioning Merkel in relation to himself, as the German transcript implies. 
At this press conference, simultaneous interpreting was provided (the video shows both politicians using headphones). For Merkel's turns, only the interpreter's rendition into French is audible. To access the original German text, we need to rely on the German transcript on the website of the German government. In the process of recontextualising the actual discursive event of the press conference to a transcript of this event on the website, some transformations occurred, such as omissions and grammatical and stylistic enhancements. Small talk and metacommunicative comments as in the extract above are typical features which are deleted before the transcript is released on the German government website. This, however, also means that a part of what the interpreter said is inaccessible to the general public and to a researcher. It is thus impossible to investigate whether the confusion about who should take on the role of the respondent was caused by the interpreter's formulation or not. Judging by the body language and facial expressions, both politicians seem to have been genuinely confused as to who was supposed to answer.

Later in this press conference, a question addressed in French to Chancellor Merkel led to an exchange between Sarkozy and the journalist (11 turns in total), which is reproduced in a shortened version below (for a more detailed analysis of this extract for the investigation of follow-ups see Schäffner 2015):

(7a) Question: Madame la Chancelière, pour suivre la question de ma consœur, vous avez laissé bercer votre intention de soutenir la candidature du président de la République. Pouvez-vous nous dire pourquoi?

Sarkozy: C'est vous qui annoncez ma candidature ce matin.

Question: Non, pas du tout. [...]

Question: C'est vrai que l'on a tous ressenti, ici, que cette émission de télévision que vous faîtes en commun ce soir est peut-être aussi une preuve du soutien que Madame la Chancelière vous apporte, peut-être que je me trompe?

[Literally: Question: Madam Chancellor, to follow on from my colleague's question, you have expressed your intention to support the candidacy of the president. Can you tell us why?

Sarkozy: It is you who announced my candidacy this morning.

Question: No, not at all. [...]

Question: It is true that we have all felt that you doing a joint TV programme tonight is probably also proof that Madam Chancellor is supporting you, or am I perhaps mistaken?]

Since the initial question was explicitly addressed to the German Chancellor, Sarkozy's intervention is, strictly speaking, not in a coherent relationship to the preceding turn. In terms of interactional roles, he assumes speaking rights which are not motivated by the questioner's communicative intention. By doing so, he positions himself in his social role as an authority, as the only person authorised to declare his candidacy. Although such longer exchanges between a politician and a journalist are rather untypical of press conferences, they too contribute to the positioning of the participants. At press conferences, journalists have their own social roles and their own aims, which can be reflected in complex question forms which may incorporate 
previous discourse (which too is a case of recontextualisation). Sarkozy did not object to the question as such, but rather its formulation. He challenges the journalist, positioning her as having overstepped her role, which can be seen as face-threatening. By interrupting the expected question-answer sequence, he interferes in terms of agenda management. The journalist in turn positions herself partly as apologetic (using excusez-moi during the exchange) and hedging her words in the justification she provides for the formulation of her question.

The whole exchange was very rapid, which must have caused problems for the simultaneous interpreter. The German version of the transcript is significantly shorter, with the exchange between Sarkozy and the journalist condensed to six turns (and words by Sarkozy wrongly attributed to the journalist):

(7b) Frage: Frau Bundeskanzlerin, ich schließe an das an, was meine Kollegen gefragt haben. Sie haben gesagt, dass Sie die Kandidatur des französischen Präsidenten unterstützen möchten. Können Sie uns sagen, warum Sie das tun?

Sarkozy: Sie haben jetzt meine Kandidatur angekündigt, wenn ich das richtig verstehe. [...]

Frage: Sie machen heute ein gemeinsames Fernsehinterview. Das ist vielleicht auch ein Beweis für die Unterstützung der Bundeskanzlerin in Ihre Richtung.

The voice of the German interpreter cannot be heard in the video, and Merkel is not visible during this exchange sequence. It is therefore impossible to say whether the German transcript records everything the interpreter had said or only part of it. It is equally difficult to judge whether Merkel succeeded in realising who had said what, although she surely realised what was going on in terms of positioning. After the journalist managed to resume her initial line of questioning, Merkel at first elaborates more generally on good traditions in Franco-German cooperation and concludes her turn by saying:

(8a) Merkel: Ich unterstütze Nicolas Sarkozy in jeder Fasson, weil wir einfach miteinander zu befreundeten Parteien gehören egal, was er tut.

[Literally: I support Nicolas Sarkozy in every respect, simply because we belong to parties that are close friends, irrespective of what he does.]

The complete French transcript has one additional sentence at the end (literally: 'This is in respect of the candidacy'):

(8b) Merkel: Je soutiens Nicolas SARKOZY sur tous les plans, parce que nous appartenons à des partis amis, de toute façon.

Cela, c'était par rapport à la candidature.

This last sentence is formally set off from the preceding statement in the French transcript and appears on a new line. A more detailed analysis is again possible by including the video which shows that Merkel had actually finished her statement with the words egal, was er tut. This statement led to some murmur and laughter in the audience, which prompted Merkel to add the 
clarifying comment, uttered with a smile, and interpreted as seen in the transcript. Her own words (In Bezug auf die Kandidatur, wollte ich nur sagen) are difficult to hear in the video due to the simultaneous interpreting and were not included in the transcript on the German government website. The mass media overwhelmingly evaluated Merkel's explicit support for Sarkozy's candidacy as inappropriate interference in the French election campaign. The recontextualisation processes from press conferences to media reports thus result in additional shifts in the positioning of politicians.

\section{Conclusion: Scope and limitations of discourse analysis for analysing interpreter- mediated encounters}

Research in discourse analysis (e.g., Weizman 2008; Clayman and Heritage 2002b) has shown that political interviews and press conferences are more than information and opinion-gathering events. They are also sites where participants are positioned and their identities constructed. When press conferences are mediated by an interpreter, they turn into triadic exchanges, which makes positioning and identity construction more complex. In this article, empirical data are provided which indicate discursive features of speaker positioning at interpreter-mediated press conferences. The qualitative study of a small set of examples has also illustrated that including a variety of sources can enrich the analysis, which, moreover, may lead to different interpretations.

The very fact that a press conference is mediated by an interpreter does not significantly impact on the aims and the conventions of this discursive event, but on the dynamics of the exchange. The presence of interpreters can have a subtle impact on negotiating speaker roles, agenda management, and interactional organisation. However, actual changes in the positioning and representation of a politician are only rarely the result of the interpreter's rendering (as in Example 1) and may be caused by contextual factors. That changes in speaker positioning may occur as a result of the arrangements for providing interpreting has been illustrated elsewhere (Schäffner 2012c) with a press conference of US President Obama and the Chinese President $\mathrm{Hu}$. In that case, a change from simultaneous to consecutive interpreting resulted in an extension of the scheduled time and led to interpreting itself becoming a topic, both in the journalists' questions and in subsequent media reports. Additional changes or modifications in the positioning of a politician can occur in the context of recontextualisation processes (providing a transcript on a government website and/or reporting in the mass media), thus also affecting the construction of politics and politicians. This, however, also happens with press conferences without interpreting.

For this article, published transcripts of press conferences were used, complemented by video recordings, and the analysis has drawn on discourse analysis. I have tried to illustrate that the various levels subsumed in (critical) discourse analysis and sociopragmatics, such as turntaking mechanisms, face work, discursive role performance and identity construction can also be employed for investigating interpreter-mediated encounters. However, the analysis has also been limited by the fact that the discursive events themselves were not directly observed. Even if video recordings were available, they did not allow the voices of all participants, including the voice of the interpreter, to be heard, nor did they give insight into the spatial arrangements. 
There are thus methodological limitations to revealing correlations between a discursive practice and its institutional setting. For a more comprehensive understanding of interpretermediated press conferences we would therefore need to combine a discourse analysis with a sociological one, exploring agency and decision-making processes behind press conference arrangements and the subsequent steps in putting transcripts on websites. At international press conferences, politicians "perform political actions in the public, mediatized arena" (Fetzer and Bull 2013, 85). Interpreters too, perform in such an arena. An analysis of interpreter-mediated press conferences can thus give more visibility to this significant role of interpreting for constructing politics and politicians. 


\section{References}

Baker, Mona. 1997. "Non-cognitive Constraints and Interpreter Strategies in Political Interviews." In Translating Sensitive Texts: Linguistic Aspects, ed. by Karl Simms, 111-129. Amsterdam: Rodopi.

Baker, Mona. 2006. "Contextualization in Translator- and Interpreter-Mediated Events." Journal of Pragmatics 38 (3): 321-337.

Baker, Paul, Costas Gabrielatos, Majid Khosravinik, Michał Krzyżanowski, Tony McEnery, and Ruth Wodak. 2008. "A Useful Methodological Synergy? Combining Critical Discourse Analysis and Corpus Linguistics to Examine Discourses of Refugees and Asylum Seekers in the UK Press." Discourse \& Society 19 (3): 273-306.

Bhatia, Aditi. 2006. "Critical Discourse Analysis of Political Press Conferences." Discourse \& Society 17 (2): 173-203.

Bull, Peter, and Anita Fetzer. 2006. "Who are We and Who Are You? The Strategic Use of Forms of Address in Political Interviews." Text \& Talk 26 (1): 3-37.

Clayman, Steven E., and John Heritage. 2002a. The News Interview. Journalists and Public Figures on the Air. Studies in Interactional Sociolinguistics 16. Cambridge: Cambridge University Press.

Clayman, Steven E., and John Heritage. 2002b. "Questioning Presidents: Journalistic Deference and Adversarialness in the Press Conferences of Eisenhower and Reagan." Journal of Communication 52 (4): 749-775.

Ekström, Mats, and Marianna Patrona, eds. 2011. Talking Politics in Broadcast Media. Crosscultural Perspectives on Political Interviewing, Journalism and Accountability. Discourse Approaches to Politics, Society and Culture 42. Amsterdam: John Benjamins.

Fetzer, Anita. 2007. "Challenges in Political Interviews: An Intercultural Analysis.” In Political Discourse in the Media, ed. by Anita Fetzer, and Gerda Lauerbach, 163-195. Amsterdam: John Benjamins.

Fetzer, Anita, and Peter Bull. 2013. "Political Interviews in Context." In Analyzing Genres in Political Communication, ed. by Piotr Cap, and Urszula Okulska, 73-99. Amsterdam: John Benjamins.

Hatim, Basil, and Ian Mason. 1990. Discourse and the Translator. London: Longman.

Heritage, John, and Steven E. Clayman. 2013. "The Changing Tenor of Questioning over Time. Tracking a Question Form across US Presidential News Conferences, 19532000." Journalism Practice 7 (4): 481-501.

Mason, Ian (ed.). 2001. Triadic Exchanges. Studies in Dialogue Interpreting. Manchester: St. Jerome.

Montgomery, Martin. 2011. "The Accountability Interview, Politics and Change in UK Public Service Broadcasting." In Talking Politics in Broadcast Media. Cross-cultural Perspectives on Political Interviewing, Journalism and Accountability, ed. by Mats Ekström, and Marianna Patrona, 33-55. Amsterdam: John Benjamins.

Munday, Jeremy. 2012. Evaluation in Translation. Critical Points of Translator DecisionMaking. Abingdon: Routledge. 
Schäffner, Christina. 2012a. "Press Conferences and Recontextualisation." In Ensayos sobre traducción jurídica e institucional. Essays on Legal and Institutional Translation, ed. by Icíar Alonso Araguás, Jesús Baigorri Jalón, and Helen J. L. Campbell, 69-83. Granada: Editorial Comares.

Schäffner, Christina. 2012b. "Unknown Agents in Translated Political Discourse." Target 24 (1): 103-125.

Schäffner, Christina. 2012c. "Follow-Ups and Interpreter-Mediated Discourse." In Proceedings of the ESF Strategic Workshop on Follow-Ups across Discourse Domains: A Cross-cultural Exploration of Their Forms and Functions, ed. by Anita Fetzer, Elda Weizman, and Elisabeth Reber, 236-247. Würzburg: Universität Würzburg. http://opus.bibliothek.uni-wuerzburg.de/volltexte/2012/7165/

Schäffner, Christina. 2015. "Follow-Ups in Interpreter-Mediated Interviews and Press Conferences." In Follow-Ups in Political Discourse: Explorations across Contexts and Discourse Domains, ed. by Elda Weizman, and Anita Fetzer, 205-230. Amsterdam: John Benjamins.

van Dijk, Teun A. 2008. Discourse and Power. Basingstoke: Palgrave Macmillan.

Wadensjö, Cecilia. 2000. "Co-constructing Yeltsin - Explorations of an Interpreter-Mediated Political Interview." In Intercultural Faulttines. Research Models in Translation Studies I: Textual and Cognitive Aspects, ed. by Maeve Olohan, 233-252. Manchester: St. Jerome.

Wadensjö, Cecilia. 2009. "Clinton's Laughter: On Translation and Communication in TV News." CTIS Occasional Papers 4: 71-86.

Weizman, Elda. 2008. Positioning in Media Dialogue. Dialogue Studies 3. Amsterdam: John Benjamins.

Wodak, Ruth, and Michael Meyer, eds. 2001. Methods of Critical Discourse Analysis. London: Sage.

Author's address

Christina Schäffner

School of Languages and Social Sciences

Aston University

Aston Triangle

Birmingham B4 7ET

UK

c.schaeffner@aston.ac.uk 